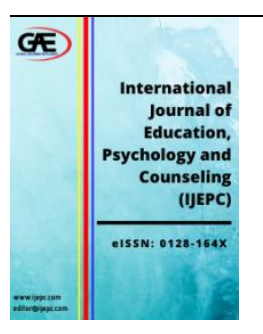

International Journal of Education, Psychology and Counselling (IJEPC)

\title{
INVESTIGATING INSTRUCTIONAL LEADERSHIP, TRANSFORMATIONAL LEADERSHIP, SELF-EFFICACY AND TRUST AMONG PRIMARY SCHOOL TEACHER
}

\author{
Jumadi Bin Musa ${ }^{1}$, Mohamad Nizam Bin Nazarudin2*, Zakiah Binti Noordin ${ }^{3}$, Nur Afny Juati ${ }^{4}$,
} Hujaimah@Siti Syafiqah Bt Juhumin ${ }^{5}$

1 Rural Education Unit, Faculty of Psychology and Education, Universiti Malaysia Sabah, Kota Kinabalu, Sabah

2 Rural Education Unit, Faculty of Psychology and Education, Universiti Malaysia Sabah, Kota Kinabalu, Sabah

Email: mnizam@ums.edu.my

3 Institut Pendidikan Guru Kampus Gaya, Sabah

Email: zakiahnoordin@gmail.com

4 Rural Education Unit, Faculty of Psychology and Education, Universiti Malaysia Sabah, Kota Kinabalu, Sabah

5 Rural Education Unit, Faculty of Psychology and Education, Universiti Malaysia Sabah, Kota Kinabalu, Sabah

* $\quad$ Corresponding Author

\section{Article Info:}

Article history:

Received date:02.06.2020

Revised date: 12.06 .2020

Accepted date: 14.06 .2020

Published date: 15.06.2020

\section{To cite this document:}

Musa, J., Nazarudin, M. N., Noordin, Z., Juati, N. A. \& Juhumin, H. S. (2020). Investigating Instructional Leadership, Transformational Leadership, Self-Efficacy and Trust among Primary School Teacher. International Journal of Education, Psychology and Counseling, 5 (35), 237-248.

DOI: $10.35631 /$ IJEPC.5350021.

\begin{abstract}
:
The purpose of this study is to investigate the relationship between headmaster instructional leadership, headmaster transformational leadership, self-efficacy, and trust among primary school teachers. Furthermore, the study aims to examine the role of gender, age, and teaching experience in headmaster instructional leadership, headmaster transformational leadership, and self-efficacy. The participants were selected by proportional stratified sampling and simple random selection. This study adopted a survey research design that utilized an ex-post facto research type in which the researcher used questionnaires to collect data from the respondents. The instruments used are the Principal Instructional Management Rating Scale (PIMRS), Multi-factor Leadership Questionnaire (MLQ), Teachers' Sense of Efficacy Scale (TSES), and Trust Scale - Trust in Principal. A total of 297 respondents (mean age $37.4+1.5$ years) from 71 schools were involved in this study. The data gathered from the respondents were downloaded into the Statistical Package for the Social Sciences (SPSS) for quantitative analysis. The results of the study indicate that there is a positive significant relationship between headmaster instructional leadership $(\mathrm{r}=.708, \mathrm{p}<.05)$, headmaster transformational leadership $(r=.683, p<.05)$, self-efficacy $(r=.615, p<.05)$ and trust. It is found there is no significant difference among primary school teachers of different ages and teaching experience concerning their headmaster instructional leadership $[\mathrm{F}(2,296)=1.533, \mathrm{p}>0.05][\mathrm{F}(2,296)$ $=.878, \mathrm{p}>0.05]$, headmaster transformational leadership $[\mathrm{F}(2,296)=.396$, $\mathrm{p}>0.05][\mathrm{F}(2,296)=.396, \mathrm{p}>0.05]$ and teacher efficacy $[\mathrm{F}(2,296)=1.164$, $\mathrm{p}>0.05][\mathrm{F}(2,296)=1.204, \mathrm{p}>0.05]$. The present study gains significance
\end{abstract}


as the results can assist the teachers and organizations in enhancing the thrust of teachers.

Keywords:

Instructional Leadership, Transformational Leadership, Self-Efficacy, Trust, Headmaster, Teacher, Primary School

\section{Introduction}

According to McKenzie (2011), if teachers trust their principals like their colleagues, students and parents, they will exhibit additional role behaviours such as a spirit of loyalty and this trust is one of the factors that differentiate between effective schools and non-effective ones (Tarter, Sabo \& Hoy, 1995; Bryk \& Schnider, 2002). Trust in school can divide into four aspects including trust in colleagues, headmaster, student, and parent (Hoy and TschannenMoran, 2003). Hoy and Tschannen-Moran (1999) believe the teacher's trust in the headmaster is essential and basis of trust in schools. Teacher's trust in the headmaster is built upon their willingness to depend on the headmaster, since he/she is perceived as reliable, kind, honest, and trustworthy (Tschannen-Moran and Hoy, 1998). This will lead to collaboration and open communication among the teachers and their clients (Tschannen-Moran, 2004). Bottery (2004) believe that when people have built trust, they have a stronger belief in self-efficacy to further raise up their interpersonal altruism. However, efficacy tend to be neglected in the field of the school context. School leader is a key lever in school reform next to teaching (Hallinger \& Heck, 1998; Leithwood, Louis, Anderson, \& Wahlstrom, 2004; Supovitz, Sirinides, \& May, 2010; Waters, Marzano, \& McNulty, 2003). The research finding support the importance of instructional leadership to the professional practice of school headmaster (Hallinger, 2011; Leithwood \& Jantzi, 2000; Robinson, Lloyd, \& Rowe, 2008).

School mission, managing the instructional programs, and promoting the school climate defined by leadership (Hallinger \& Heck, 1998). Instructional leadership influenced leaders identify the direction for the school, motivate staff, and coordinate school and classroombased strategies aimed at improvements in teaching and learning (Hallinger \& Murphy, 2012). Headmaster required to exhibit strong skills and instructional leadership expertise in improving schools in the 21st century (Hallinger, 2011; Hallinger \& Heck, 2010; Leithwood et al., 2008). Teacher trust in headmaster influenced directly by transformational leadership (Tschannen-moran, 2003; Podsakoff, MacKenzie, Moorman, \& Fetter, 1990; Pillai, Schriesheim, \& Williams, 1999; Jung \& Avolio, 2000; Gillespie \& Mann, 2004; Dirks \& Ferrin, 2002; Bass \& Riggio, 2006). Transformational leaders motivate followers to perform beyond expectations (Bass, 1985) and to change expectations, perceptions, and motivations to work towards common goals. The transformation could be achieved by raising the awareness of the value of designated outcomes, getting followers to go beyond their own lower level and short-term self-interests, or expanding follower's needs on Maslow's hierarchy of needs. Teachers' sense of efficacy is largely dependent on the number of efforts devoted to their teaching, their decision-making ability, and the degree of persistence in solving problematic issues (Chong et al, 2019). School management and policymaker are urged to develop effective human resources initiatives and programs that can create a trusting relationship in the organization and enhance teachers' self-efficacy (Ling, Nazarudin \& Noordin, 2019).

\section{Problem Statement}

Various educational problems have occurred lately. Some of the problems that have occurred are the reform of the education system, the supply of textbooks, school uniforms, school shoes, the increase in salaries and allowances, and many others that have hampered the 
development of education in Malaysia. All of these problems have contributed to the increasing burden on teachers both financially and mentally and emotionally. According to Muhiyuddin and Hashim (2006), it has been found that the burden of teacher duties in schools has caused a great deal of dissatisfaction and injustice among teachers. As a result, teachers feel they have been burdened by the changing role of teachers in the education system. This change has resulted in teachers not only functioning as educators but also as clerks as a result of many clerical tasks performed by teachers. As a result of the efforts to address dissatisfaction and mistrust among teachers, the headmaster needs to be effective agents to change this situation so that teachers in schools become more effective, efficient, skilled, innovative, creative, relational, and futuristic in carrying out teaching and learning tasks another side (Nazarudin, Abdullah \& Noordin, 2017).

The Education Development Master Plan (2013-2025) found that supervision of teaching and learning by teachers indicated that $12 \%$ of teachers' teaching was delivered at high standards, while another $38 \%$ was at a satisfactory level and $50 \%$ of teacher teaching was unsatisfactory. Is the issue closely related to the headmaster's overreaction at school? or teachers do not believe in the leadership capabilities, transformational practices, and effectiveness of the school headmaster? So, to fulfil that desire, the headmaster plays a very important role so that the teachers can perform the assigned tasks effectively. This desire, however, is difficult to achieve without the confidence of the headmaster among the teachers. What is often overlooked in the leadership of a headmaster is instructional leadership. Teachers will see the actions and efforts that the headmaster will take in developing the teaching and learning process and in determining school success. If the headmaster can change the school climate towards more positive change, the teachers will be able to do the job effectively. Taking into account all of these statements of concern, this study was conducted to assess the extent to which teachers believe in the headmaster in their respective schools so that appropriate measures can be taken.

\section{Research Purpose}

The purpose of this study was to investigate the relationship between headmaster instructional leadership, headmaster transformational leadership, self-efficacy, and trust among primary schools teachers.

\section{Methods}

\section{Participants}

Primary schools teachers from Ranau district (mean age $37.4+1.5$ years) have volunteered to take part as participants. To determine the sample size of 1308 respondents in the Ranau district primary school teachers, the researcher refers to the determination of sample size tables built by Krejcie and Morgan (1970). A total of 297 participants were selected at random from 71 primary schools in Ranau district. A total of 120 participants were 23 to 33 years $(40.4 \%), 149(50.2 \%)$ were aged 34 to 44 years and $28(9.4 \%)$ were aged over 44 years. A total of 120 participants $(40.4 \%)$ had teaching experience between 1 to 7 years, 135 $(45.5 \%)$ between 8 to 14 years, and $42(14.1 \%)$ over 14 years (Table 1$)$. 
Table 1: Distribution Participant Ages And Teaching Experiences

\begin{tabular}{llll}
\hline & $23-33$ years & $34-44$ years & $>44$ years \\
Age & $120(40.4 \%)$ & $149(50.2 \%)$ & $28(9.4 \%)$ \\
\hline Teaching & $1-7$ years & $8-14$ years & $>14$ years \\
Experience & $120(40.4 \%)$ & $135(45.5 \%)$ & $42(14.1 \%)$ \\
\hline
\end{tabular}

$\mathrm{N}=297$

\section{Instrument and Data Analyses}

Four questionnaires were used in this study and teachers were respondents to the questionnaires. All of the questionnaires items were presented in Malay language. To make sure meaning uniformity across the two cultures all of the items were translated from English into Malay and then back translated into English. Two education professors fluent in Malay and English language have evaluated the two translations and the best items were selected for Pilot surveys. Pilot surveys were administrated to a sample of primary school teachers also in Ranau district. Results demonstrate that translated items were appropriate. After developing the final version, data were collected at regularly planned teacher meetings. In each school, researchers explained the general purpose of the study and assured the confidentiality of all responses.

Principal Instructional Management Rating Scale (PIMRS; Hallinger \& Murphy, 1987) is the 50-item principal version asks respondents to rate, on a Likert-type scale, how frequently they perceive themselves enacting specific instructional leadership behaviors in the schools they lead ( $1=$ Almost Never, $5=$ Almost Always). Behaviors measured by the scale have been defined in the literature as best practices demonstrated by principal's ineffective schools. Transformational leadership was measured with the twenty items of Multi-factor leadership Questionnaire (5X - short) developed by Bass and Avolio (2000). Teachers were asked to describe the extent to which they agree with items on a 5-point Likert scale ranging from 1 (strongly disagree) to 5 (strongly agree). These items measure four components of transformational leadership including idealized influence, inspirational motivation, intellectual stimulation, and individualized consideration.

Teacher Sense Efficacy Scale (TSES; Tschannen-Moran \& Hoy, 2001) includes three dimensions: (a) efficacy for instructional strategies (IS), which captures teachers' sense of efficacy in developing and implementing IS to meet students' needs; (b) efficacy for classroom management (CM), which captures teachers' sense of efficacy in maintaining classroom order and helping students follow rules; and (c) efficacy for student engagement (SE), which teachers were asked to describe the extent to which they agree with items on a 5point Likert scale ranging from 1 (nothing) to 9 (a great deal). The Omnibus T-Scale (Hoy \& Tschannen-Moran, 2003) was used to measure the level of trust between the teachers and the principals. Eight of the entire items specifically measure trust in principal. Teachers were asked to describe the extent to which they agree with items on a 5-point Likert scale ranging from 1 (strongly disagree) to 5 (strongly agree).

The coefficient alphas for Principal Instructional Management, transformational leadership, teacher efficacy, and trust were $0.82,0.68,0.88$ and 0.88 respectively. The data gathered from the respondents were downloaded into the Statistical Package for the Social Sciences (SPSS) for quantitative analysis. The statistical tests employed in this study were Mean, Copyright $\odot$ GLOBAL ACADEMIC EXCELLENCE (M) SDN BHD - All rights reserved 
Standard Deviation, independent t-test, one-way ANOVA, and Pearson product moment correlation (Table 2).

Table 2: Instrument and Statistical Tests

\begin{tabular}{|c|c|c|c|}
\hline No & Objectives & Instruments & $\begin{array}{c}\text { Statistical } \\
\text { Test }\end{array}$ \\
\hline 1 & $\begin{array}{l}\text { To examine the level of headmaster } \\
\text { instructional leadership, headmaster } \\
\text { transformational leadership, and self- } \\
\text { efficacy among primary schools teachers. }\end{array}$ & Questionnaires & $\begin{array}{l}\text { Mean \& } \\
\text { Standard } \\
\text { Deviation }\end{array}$ \\
\hline 2 & $\begin{array}{l}\text { To indicate the differences among } \\
\text { different gender, age, and teaching } \\
\text { experience groups of primary schools } \\
\text { teachers concerning their headmaster } \\
\text { instructional, headmaster leadership, } \\
\text { transformational leadership, and self- } \\
\text { efficacy. }\end{array}$ & Questionnaires & $\begin{array}{l}\text { t-test \& one- } \\
\text { way ANOVA }\end{array}$ \\
\hline 3 & $\begin{array}{l}\text { To identify the relationship between } \\
\text { headmaster instructional leadership, } \\
\text { headmaster transformational leadership, } \\
\text { and self-efficacy and trust among primary } \\
\text { schools teachers. }\end{array}$ & Questionnaires & $\begin{array}{l}\text { Pearson } \\
\text { product } \\
\text { moment } \\
\text { correlation }\end{array}$ \\
\hline
\end{tabular}

\section{Results}

In this study three research objectives have been investigated.

\section{Level of Headmaster Instructional Leadership, Headmaster Transformational Leadership, and Self-Efficacy among Primary Schools Teachers}

Table 3 shows the level of scales and sub-scales. Based on the table, headmaster instructional leadership $(m=4.18)$, teacher self-efficacy $(m=4.18)$, and teacher trust $(m=4.37)$ were at a high level except for the headmaster's transformational level $(\mathrm{m}=3.56)$ is at an intermediate level.

Table 3: Level of Scales and Sub Scales

\begin{tabular}{|c|c|c|c|c|}
\hline Scale & $\begin{array}{c}\text { Sub-scales } \\
\end{array}$ & Mean & SD & Level \\
\hline \multirow{4}{*}{$\begin{array}{l}\text { Headmaster } \\
\text { Instructional } \\
\text { Leadership }\end{array}$} & Defining the School Mission & 4.20 & 0.5916 & High \\
\hline & $\begin{array}{l}\text { Managing the Instructional } \\
\text { Program }\end{array}$ & 4.08 & 0.6609 & High \\
\hline & $\begin{array}{l}\text { Developing the School Learning } \\
\text { Climate }\end{array}$ & 4.27 & 0.5863 & High \\
\hline & Overall & 4.18 & 0.6129 & High \\
\hline $\begin{array}{l}\text { Headmaster } \\
\text { Transformatio } \\
\text { nal Leadership }\end{array}$ & Individualized Consideration & 3.96 & 0.5818 & High \\
\hline
\end{tabular}




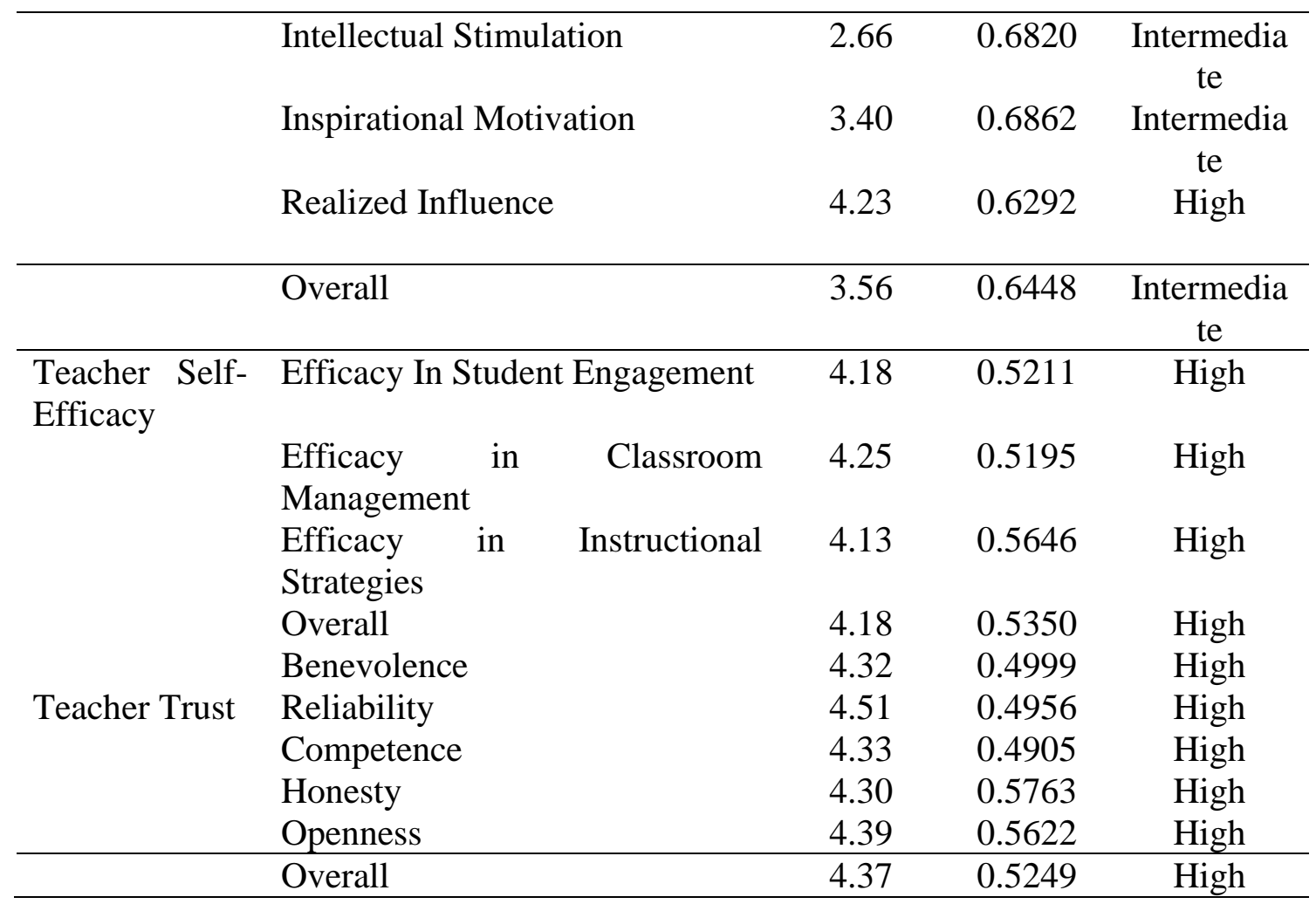

Differences among Different Gender, Age, and Teaching Experience Groups of Primary Schools Teachers Concerning Their Headmaster Instructional, Headmaster Leadership, Transformational Leadership, And Self-Efficacy

T-Test resulted no significant differences in headmaster instructional leadership $(\mathrm{t}=-1.23$; $\mathrm{p}>0.05)$ and teacher self-efficacy $(\mathrm{t}=-.974 ; \mathrm{p}>0.05)$ but there are significant differences in headmaster transformational leadership $(\mathrm{t}=-.867 ; \mathrm{p}<0.05)$ by gender (Table 4$)$.

Table 4: T-Test for Comparison between Genders

\begin{tabular}{|c|c|c|c|c|c|c|}
\hline & ender & $\mathbf{N}$ & Mean & $\begin{array}{c}\text { Std. } \\
\text { Deviation }\end{array}$ & $\mathbf{t}$ & Sig \\
\hline \multirow{2}{*}{$\begin{array}{l}\text { Headmaster } \\
\text { Instructional } \\
\text { Leadership }\end{array}$} & Male & 143 & 87.6923 & 5.66087 & -1.23 & .785 \\
\hline & Female & 154 & 88.5325 & 6.04035 & & \\
\hline \multirow{2}{*}{$\begin{array}{l}\text { Headmaster } \\
\text { Transformational } \\
\text { Leadership }\end{array}$} & Male & 143 & 67.1399 & 4.12584 & -.867 & .026 \\
\hline & Female & 154 & 67.6039 & 5.01816 & & \\
\hline \multirow{2}{*}{$\begin{array}{l}\text { Teacher } \\
\text { Efficacy }\end{array}$} & Male & 143 & 49.9860 & 4.41984 & -.974 & .698 \\
\hline & Female & 154 & 50.4935 & 4.54498 & & \\
\hline
\end{tabular}

Table 5 shows one way ANOVA test result revealed headmaster instructional leadership [F $(2,296)=1.533, \mathrm{p}>0.05]$, headmaster transformational leadership $[\mathrm{F}(2,296)=.396, \mathrm{p}>$ $0.05]$ and teacher efficacy $[\mathrm{F}(2,296)=1.164, \mathrm{p}>0.05]$ did not show significant differences by age. 
Table 5: One-way ANOVA Test for Comparison between Ages

\begin{tabular}{lccccc}
\hline $\begin{array}{l}\text { Headmaster } \\
\begin{array}{l}\text { Instructional } \\
\text { leadership }\end{array}\end{array}$ & $\begin{array}{c}\text { Sum of } \\
\text { Squares }\end{array}$ & df & $\begin{array}{c}\text { Mean } \\
\text { Square }\end{array}$ & F & Sig. \\
\hline Between Groups & 105.111 & 2 & 52.556 & 1.533 & .218 \\
Within Groups & 10080.027 & 294 & 34.286 & & \\
Total & 10185.138 & 296 & & & \\
\hline $\begin{array}{l}\text { Headmaster } \\
\text { Transformational }\end{array}$ & & & & & \\
Leadership & & & & & \\
\hline Between Groups & 16.888 & 2 & 8.444 & .396 & .673 \\
$\begin{array}{l}\text { Within Groups } \\
\text { Total }\end{array}$ & 6269.119 & 294 & 21.324 & & \\
\hline Teacher Efficacy & 6286.007 & 296 & & & \\
\hline Between Groups & 46.786 & 2 & 23.393 & 1.164 & .314 \\
Within Groups & 5906.776 & 294 & 20.091 & & \\
Total & 5953.562 & 296 & & & \\
\hline
\end{tabular}

Table 6 shows there was also no significant difference in headmaster instructional leadership $[\mathrm{F}(2,296)=.878, \mathrm{p}>0.05]$, headmaster transformational leadership $[\mathrm{F}(2,296)=.410, \mathrm{p}>$ $0.05]$ and teacher self-efficacy $[\mathrm{F}(2,296)=1.204, \mathrm{p}>0.05]$ based on years of teaching experience.

Table 6: One way ANOVA Test for Comparison between Teaching Experience

\begin{tabular}{lccccc}
\hline $\begin{array}{l}\text { Headmaster } \\
\text { Instructional } \\
\text { leadership }\end{array}$ & $\begin{array}{c}\text { Sum of } \\
\text { Squares }\end{array}$ & df & $\begin{array}{c}\text { Mean } \\
\text { Square }\end{array}$ & F & Sig. \\
\hline Between Groups & 60.461 & 2 & 30.230 & .878 & .417 \\
Within Groups & 10124.677 & 294 & 34.438 & & \\
Total & 10185.138 & 296 & & & \\
\hline $\begin{array}{l}\text { Headmaster } \\
\text { Transformational }\end{array}$ & & & & & \\
Leadership & 17.487 & 2 & 8.744 & .410 & .664 \\
\hline Between Groups & 6268.520 & 294 & 21.321 & & \\
Within Groups & 6286.007 & 296 & & & \\
Total & & & & & \\
\hline Teacher Efficacy & 48.371 & 2 & 24.185 & 1.204 & .301 \\
\hline Between Groups & 5905.192 & 294 & 20.086 & & \\
Within Groups & 5953.562 & 296 & & & \\
Total & & & & & \\
\hline
\end{tabular}

Relationship Between Headmaster Instructional Leadership, Headmaster Transformational Leadership, Self-Efficacy and Trust Among Primary Schools Teachers Regression analysis shows there was a significant strong positive relationship between headmaster instructional leadership $(\mathrm{r}=.708, \mathrm{p}<.05)$, headmaster transformational leadership $(\mathrm{r}=.683, \mathrm{p}<.05)$, self-efficacy $(\mathrm{r}=.615, \mathrm{p}<.05)$ trust among primary schools teachers. (Table 7). 
Table 7: Regression Analysis

\begin{tabular}{lccc}
\hline & $\begin{array}{c}\text { Headmaster } \\
\text { Instructional } \\
\text { Leadership }\end{array}$ & $\begin{array}{c}\text { Headmaster } \\
\text { Transformational } \\
\text { Leadership }\end{array}$ & Teacher Efficacy \\
\hline $\begin{array}{l}\text { Teacher } \\
\text { Trust }\end{array}$ & $.708^{* *}$ & $.683^{* *}$ & $.615^{* *}$ \\
$\mathrm{~N}=297$ & & \\
$* *$. Correlation is significant at the 0.01 level (2-tailed). & & \\
\end{tabular}

\section{Discussion and Conclusion}

Headmaster transformational leadership in Ranau district is at an intermediate level. There is a need to increase headmaster transformational leadership in the future. According to Bass (1985) transformation could be achieved by raising the awareness of the value of designated outcomes, getting followers to go beyond their own lower level and short-term self-interests, or expanding follower's needs on Maslow's hierarchy of needs. Bass (1985) also suggested that there were four different components of transformational leadership: 1. Intellectual stimulation: leader challenges the status-quo, encourages creativity, and encourages followers to look at new ways of doing things and new learning opportunities 2. Individualized consideration: leader offers support and encouragement to individual followers. He/she aware of each individual's ability, talents, and potential, thus create a new opportunity for them 3 . Inspirational motivation: the leader has a clear vision and goals that he/she can articulate to followers. He/she is also able to help followers experience the same passion and motivation to fulfil these goals. He/she could inspire and motivate followers to accomplish goals perceived to be difficult to attain 4. Idealized influence: The leader serves as a role model for followers. Because followers trust and respect the leader, they follow the leader and internalize his or her ideals.

A female teacher has higher perceptions of headmaster transformational leadership. There are no studies that have examined perceptions of teachers' from a different gender. While there is data to indicate that women leaders employ different leadership styles than men (Grant, 1988; Kabacoff, 2001; Karau \& Eagly, 1999; Kim \& Shim, 2003; Rosener, 1990), few articles have looked at the specific behaviors employed by women vs. men. Further, recent studies (Chemers et al., 2000; Morgan, 2004; Anderson et al., 2006) suggest that there is little difference in the results men and women achieve as leaders. According to Kent et al (2010) these findings indicate that leadership style has little to do with the results that leaders achieve. That is, if the leadership styles of women are different from the leadership styles of men, yet the results they achieve are similar, then leadership style must have little to do with results. The significant direct effect of transformational leadership on trust in principal is similar to the Podsakoff et al., (1990) and Pillai et al., (1999). According to Bass and Riggio (2006), trust in leader is one of the most essential variables in the process of influencing followers. Ngodo (2008) believe that transformational leaders are very successful in gaining the trust of their followers. According to Burns (1978), transformational leaders motivate the followers to a high level of commitment and loyalty to the visions of the leader. So, it is difficult for a principal who is not trusted by teachers to have high committed teachers. Also, in order to challenge the status quo and encourage teachers to look at new ways of doing things principals would need to win the trust of teachers (Zeinabadi \& Rastegarpour, 2010)

Teacher leaders can gain trust of teachers if they help them as peer's not as expert supervisors and avoid giving strict feedback about the teaching activities of the teachers (Mangin \& 
Stoelinga, 2011). They have to be facilitators by pointing out the weaknesses and showing the ways to increase the effectiveness of the activities. Teacher leaders are more effective when they are supported by the principals (Leithwood et al, 2004). Principals may inform the teachers about the roles and importance of teacher leaders to increase school effectiveness and may provide sufficient time for them to work together (Gigante \& Firestone, 2008). Coaching can be effective when supported by the principals/headmasters (Matsumura et al, 2009) and the teachers (Atteberry, 2008). Principals/headmasters can explain the importance of coaching to the teachers for improving teaching (Matsumura, 2010). According to Şenol \& Lesinger (2018), the works of the instructional leaders of a school are complementary to each other so that they have to trust and support each other. In this way, leadership can contribute to improving student learning by shaping the conditions and school climate based on the school objectives which target to meet the needs of contemporary society. Different perceptions among teachers and school administrators on educational leadership may cause problems regarding the organization of the school (Jumaniah, Zakiah \& Mohamad Nizam, 2018). This may, in turn, become a source of organizational conflict.

According to Choong (2019), teachers' positive behaviours enable them to have greater trust in their capability of handling pressures and crises. Teachers who believe that if one's behavior resulted in desirable outcomes also possess the requisite skills to deliver a positive impact. In response, he or she may be keen to exercise citizenship behaviour by helping new colleagues, go the extra mile to guide students' academic performance. Examples of teachers' extra-role behaviors towards school include generating high-quality ideas for innovation, volunteering to sponsor extra-curricular activities, and undertaking to serve local committees (DiPaola \& da Costa Neves, 2009). Teachers who are high in self-efficacy are generally successful and confident to carry out their job effectively (Zheng et al., 2018; Liu \& Hallinger, 2018).

\section{References}

Anderson, N., Lievens, F., Van Dam, K., \& Born, M. (2006). A construct-driven investigation of gender difference in a leadership-role assessment center. Journal of Applied Psychology, 91, 555-566.

Atteberry, A, Bryk, A, Walker, L, \& Biancarosa, G. (2008). Variations in the amount of coaching in literacy collaborative schools. Paper Presented at the Annual Conference of the American Educational Research Association, New York.

Bass, B. M. (1985). Leadership and performance beyond expectations. New York: The Free Press.

Bass, B. M., \& Avolio, B. J. (2000). MLQ Multifactor Leadership Questionnaire (2nd ed.). Redwood City, CA: Mind Garden.

Bass, B. M., \& Riggio, R. E. (2006). Transformational leadership. Lawrence Erlbaum Associates, Inc., Publishers.

Bottery, M. (2004). The challenges of educational leadership. Sage.

Bryk, A. S., \& Schneider, B. (2002). Trust in schools: A core resource for improvement. New York, NY: Russell Sage Foundation.

Burns, J. M. (1978). Leadership. New York: Harper and Row.

Chemers, M. M., Watson, C. B., \& May, S. T. (2000). Dispositional affect and leadership effectiveness: A comparison of self-esteem, optimism, and efficacy. Personality and Social Psychology Bulletin, 26, 267-277.

Choong, Y.O., Ng, L.P., Ai Na, S. \& Tan, C.E. (2019). The role of teachers' self-efficacy between trust and organisational citizenship behaviour among secondary school teachers. Personnel Review, 49(3), 864-886. 
Dipaola, M. \& da Costa Neves, P.M.M. (2009). Organizational citizenship behaviors in American and Portuguese public schools: measuring the construct across cultures. Journal of Educational Administration, 47 (4), 490-507.

Dirks, K. T., \& Ferrin, D. L. (2002). Trust in Leadership: Meta-Analytic Findings and Implications for Research and Practice. Journal of Applied Psychology, 87(4), 611628.

Gigante, N.A, \& Firestone, W.A. (2008). Administrative support and teacher leadership in schools implementing reform. Journal of Educational Administration. 46(3), 302-331

Gillespie, N. A., \& Mann, L. (2004). Transformational leadership and shared values: The building blocks of trust. Journal of Managerial Psychology, 19(6), 588-607.

Grant, J. (1988). Women as managers: What can they offer organizations? Organizational Dynamics, Winter. 56-63.

Hallinger, P. (1983). Accessing the instructional management behaviors of principals. Unpublished doctoral dissertation, Stanford University, Stanford, CA.

Hallinger, P. (2000). A review of two decades of research on the principal using the Principal Instructional Management Rating Scale. Paper presented at the annual meeting of the American Education Research Association, Seattle, WA.

Hallinger, P. (2008). Methodologies for studying school leadership: A review of 25 years of research using the Principal Instructional Management Rating Scale. Paper presented at the annual meeting of the American Educational Research Association, New York, NY.

Hallinger, P. (2011). Leadership for learning: Lessons from 40 years of empirical research. Journal of Educational Administration, 49(2), 125-142.

Hallinger, P., \& Heck, R. H. (1996). Reassessing the principal's role in school effectiveness: A review of empirical research, 1980-1995. Educational Administration Quarterly, $32(1), 5-44$.

Hallinger, P., \& Heck, R. H. (1998). Exploring the principal's contribution to school effectiveness: 1980-1995. School Effectiveness and School Improvement, 9(2), 157191.

Hallinger, P., \& Heck, R. H. (2010). Collaborative leadership and school improvement: Understanding the impact on school capacity and student learning. School Leadershipand Management, 30(2), 95-110.

Hallinger, P., \& Murphy, J. (1985). Assessing the instructional management behavior of principals. Elementary School Journal, 86(2), 217-247.

Hallinger, P., \& Murphy, J. (2012). Running on empty? Finding the time and capacity to lead learning. NASSP Bulletin, 97(1), 5-21.

Hallinger, P., Wang, W., \& Chen, C. (2013). Assessing the measurement properties of the Principal Instructional Management Rating Scale: A meta-analysis of reliability studies. Educational Administration Quarterly, 49(2), 272-309.

Hallinger, P., \& Wang, W., (2015). Assessing instructional leadership with the Principal Instructional Management Rating Scale. Switzerland: Springer.

Hoy, W. K., \& Tschannen-Moran, M. (2003). The conceptualization and measurement of faculty trust in schools: The omnibus T-Scale. In W. K. Hoy \& C. G. Miskel, Studies in Leading and Organizing Schools (pp. 181-208). Information Age Publishing: Greenwich: CT

Hoy, W. K., \& Tschannen-Moran, M. (1999). The five faces of trust: An empirical confirmation in urban elementary schools. Journal of School Leadership, 9, 184-208.

Jumaniah Abd Mutalib, Zakiah Noordin \& Mohamad Nizam Nazarudin (2018). Hubungan Kerja Berpasukan Dan Pengupayaan Guru Dengan Komitmen Organisasi Di Sekolah Rendah. Jurnal Ilmiah. 11, 58-71. 
Jung, D. I., \& Avolio, B. J. (2000). Opening the black box: An experimental investigation of the mediating effects of trust and value congruence on transformational and transactional leadership. Journal of organizational behaviour, 21, 949-964.

Kabacoff, R. J. (2001). Gender differences in organizational leadership. Do men and women lead differently? Briefings Publishing Group.

Karau, S. J., \& Eagly, A. H. (1999). Invited reaction: Gender, social roles, and the emergence of leaders. Human Resource Development Quarterly, 10, 321-327.

Kent, T.W., Blair, C.A., Rudd, H.F., \& Schuele, U. (2010). Gender differences and transformational leadership behavior: Do both German men women lead in the same way. International Journal of Leadership Studies, 6(1), 52-66.

Kim, H., \& Shim, S. (2003). Gender-based approach to the understanding of leadership roles among retail managers. Human Resource Development Quarterly, 14, 321-342.

Leithwood, K., Day, C., Sammons, P., Harris, A., \& Hopkins, D. (2006). Successful school leadership: What it is and how it influences pupil learning. (University of Nottingham, UK: National College of School Leadership).

Leithwood, K., Harris A., \& Hopkins, D. (2008). Seven strong claims about successful school leadership. School Leadership \& Management, 28(1), 27-42.

Leithwood, K., \& Jantzi, D. (2000). The effects of transformational leadership on organizational conditions and student engagement with the school. Journal of Educational Administration, 38(2), 112-129.

Leithwood, K., Louis, K. S., Anderson, S., \& Wahlstrom, K. (2004). How leadershipinfluences student learning. New York: The Wallace Foundation.

Leithwood K, Seashore Louis K, Anderson S, Wahlstrom K. (2004). Review of Research: How Leadership Influences Student Learning. Minneapolis: Center for Applied Research and Educational Improvement, University of Minnesota.

Ling, L., Nazarudin, M. N., \& Noordin, Z. (2019). Kepuasan Kerja dan Efikasi Guru Tingkatan Enam di Pantai Barat Sabah. International Journal of Education, Psychology and Counseling, 4 (32), 51-66.

Liu, S. \& Hallinger, P. (2018). Principal instructional leadership, teacher self-efficacy, and teacher professional learning in China: testing a mediated-effects model. Educational Administration Quarterly. 54 (4), 501-528.

Mangin M, \& Stoelinga (2011). https://learningforward.org/docs/jsd-june2011/mangin323.pdf.

Matsumura, L.C, Garnier H.E, \& Resnick, L.B. (2010). Implementing literacy coaching: Therole of school social resources. Educational Evaluation and Policy Analysis. 32(2):249-272.

Matsumura, L.C, Sartoris, M, Bickel, D. D, \& Garnier, H. E. (2009). Leadership for literacy coaching: The principal's role in launching a new coaching program. Educational Administration Quarterly. 45(5), 655-693.

McKenzie-Mohr, D. (2011). Fostering sustainable behavior: An introduction to communitybased social marketing. New society publishers.

Morgan, M. J. (2004). Women in a man's world: Gender differences in leadership at the military academy. Journal of Applied Psychology, 34(12), 2482-2502

Muhiyuddin Abdul Rahman dan Hashim Abu Bakar. (2006). Kajian Beban Tugas Guru Sekolah Rendah Di Daerah Sri Aman,Sarawak. Universiti Teknologi Malaysia.

Nazarudin, M. N., Abdullah, N. F. L. B., \& Noordin, Z. (2017). Profesionalisme, Kesediaan Mengajar Guru Pelatih Dan Penyeliaan Pengajaran Pensyarah Pembimbing Praktikum Di Institut Pendidikan Guru Zon Sabah. International Journal of Education, Psychology and Counseling (IJEPC), 2(4), 71-84. 
Ngodo, O. E. (2008). Procedural Justice and Trust: The Link in the Transformational Leadership - Organizational Outcomes Relationship. International Journal of Leadership Studies, 4(1), 82-100.

Pillai, R., Schriesheim, C., \& Williams, E. (1999). Fairness perceptions and trust as mediators for transformational and transactional leadership: A two-sample study. Journal of Management, 6, 897-933

Podsakoff, P. M., MacKenzie, S. B., Moorman, R. H., \& Fetter, R. (1990). Transformational leader behaviours and their effects on followers' trust in leader, satisfaction, and organizational citizenship behaviours. Leadership Quarterly, 1(2), 107-142.

Robinson, V., Lloyd, C., \& Rowe, K. (2008). The impact of leadership on student outcomes. An analysis of the differential effects of leadership types. Educational Administration Quarterly, 41(5), 635-674.

Rosener, J. (1990). Ways women lead. Harvard Busines Review, 119-125.

Şenol, H., \& Lesinger, F. Y. (2018). The relationship between instructional leadership style, trust and school culture. In leadership. IntechOpen.

Supovitz, J., Sirinides, P., \& May, H. (2010). How principals and peers influence teaching and learning. Educational Administration Quarterly, 46(1), 31-56.

Tarter, C. J., Sabo, D., \& Hoy, W. K. (1995). Middle school climate, faculty trust and effectiveness: a path analysis. Journal of Research and Development in Education, 29, 41-49

Tschannen-Moran, M. (2003). Fostering organizational citizenship: Transformational leadership and trust. In W. K. Hoy \& C. G. Miskel, Studies in Leading and Organizing Schools (pp. 157-179). Information Age Publishing: Greenwich: CT.

Tschannen-Moran, M. (2004). Trust matters: Leadership for successful schools. San Francisco, CA: Josey-Bass.

Tschannen-Moran, M., \& Hoy, W. (1998). Trust in schools: a conceptual and empirical analysis. Journal of Educational Administration, 36(4), 334-352.

Tschannen-Moran, M., \& Hoy, A. W. (2001). Teacher efficacy: Capturing an elusive construct. Teaching and teacher education, 17(7), 783-805.

Waters, J. T., Marzano, R. J., \& McNulty, B. A. (2003). Balanced leadership: What 30 years of research tells us about the effect of leadership on student achievement. Aurora, CO: Midcontinent Research for Education and Learning.

Zeinabadi, H., \& Rastegarpour, H. (2010). Factors affecting teacher trust in principal: testing the effect of transformational leadership and procedural justice. Procedia-Social and Behavioral Sciences, 5, 1004-1008.

Zheng, X., Yin, H. \& Li, Z. (2018). Exploring the relationships among instructional leadership, professional learning communities and teacher self-efficacy in China. Educational Management Administration \& Leadership. 47(6), 843-859. 